\title{
TAHAP KEPERCAYAAN PELAJAR SEKOLAH MENENGAH TERHADAP PEMBELAJARAN BAHASA ARAB
}

\author{
Nadhilah Abdul PISAL ${ }^{1}$ \\ Akademi Pengajian Bahasa, \\ Universiti Teknologi Mara (UiTM), \\ Cawangan Perlis, 02600 Arau, \\ Perlis, Malaysia \\ Kamarul Shukri MAT TEH ${ }^{2}$ \\ Fakulti Pengajian Kontemporari Islam, \\ Universiti Sultan Zainal Abidin, \\ Kampus Gong Badak, 21300 Kuala Terengganu, \\ Terengganu, Malaysia \\ ${ }^{1}$ ananadhilah@yahoo.com* \\ ${ }^{2}$ kamarul@unisza.edu.my
}

Manuscript received 13 March 2018

Manuscript accepted 30 April 2018

\begin{abstract}
ABSTRAK
Kepercayaan terhadap pembelajaran bahasa dapat mempengaruhi tindakan pelajar dalam pembelajaran bahasa. Selain itu, faktor kepercayaan ini juga dapat mempengaruhi pencapaian bahasa pelajar secara tidak langsung. Oleh itu, kajian ini dijalankan adalah untuk mengenal pasti jenis dan tahap kepercayaan pelajar dalam pembelajaran bahasa Arab secara keseluruhan dan berdasarkan konstruk kepercayaan utama. Seramai 350 orang pelajar tingkatan empat dari 12 buah sekolah menengah agama sekitar Kedah dipilih untuk menjawab satu set soal selidik. Data kajian ini dianalisis dengan menggunakan analisis deskriptif. Dapatan kajian menunjukkan bahawa responden kajian ini mempunyai kepercayaan yang tinggi terhadap pembelajaran bahasa secara keseluruhan serta mengikut konstruk kepercayaan utama. Responden kajian ini didapati mempunyai kepercayaan yang tinggi dalam konstruk motivasi dan harapan. Kepercayaan terendah pula diwakili oleh konstruk kebolehan semula jadi dalam pembelajaran bahasa. Kesimpulannya, pelajar mempunyai kepercayaan tersendiri terhadap pembelajaran bahasa Arab yang dibentuk berdasarkan pengalaman pembelajaran lalu. Di samping itu, kajian ini juga memberi gambaran awal tahap kepercayaan pelajar terhadap pembelajaran bahasa Arab di peringkat menengah.
\end{abstract}


Kata kunci: kepercayaan, pembelajaran bahasa, kepercayaan terhadap pembelajaran bahasa, bahasa Arab

\title{
SECONDARY SCHOOL STUDENTS' LEVEL OF BELIEF ON THE ARABIC LANGUAGE LEARNING
}

\begin{abstract}
Language learning beliefs can influence students' language learning behaviour. In addition, this belief factor can also indirectly influence students' language achievement. Hence, this study was conducted to identify the type and level of students' belief in learning the Arabic language as a whole and based on the main belief construct. A total of 350 Form Four students from 12 religious secondary schools around Kedah were surveyed. The questionnaire data were analyzed using descriptive analysis. The findings show that the respondents have a high level of belief in language learning as a whole and based on the main beliefs construct. Respondents were found to have the highest level of belief in motivation and expectations construct. The lowest level of belief is represented by the nature of language learning construct. In conclusion, students have their own beliefs in learning the Arabic language that is formed based on their past learning experiences. In addition, this study also provides preliminary insights into the level of students' belief in learning the Arabic language at the secondary schools.
\end{abstract}

Keywords: belief, language learning, belief about language learning, Arabic language

\section{Pengenalan}

Menurut Eggen dan Kauchak (2010, hlm. 297) kepercayaan merupakan "suatu idea kognitif yang diterima sebagai benar tanpa memerlukan bukti yang kukuh untuk menyokongnya". Takrifan yang dinyatakan ini menunjukkan bahawa kepercayaan merupakan suatu pandangan, persepsi atau pegangan yang diyakini terhadap sesuatu perkara yang lahir secara alami. Dalam proses pembelajaran bahasa, setiap individu mempunyai persepsi atau pandangan tersendiri terhadap pembelajaran bahasa. Persepsi atau pandangan ini merupakan kepercayaan yang diterima sebagai benar oleh pelajar. Kepercayaan ini boleh dibentuk berdasarkan pengalaman pembelajaran yang lalu (Abid, 2012; Horwitz, 1987).

Dalam proses pembelajaran, pelajar perlu aktif mencari dan mendalami bahan pembelajaran daripada pelbagai sumber dari semasa ke semasa. Walau bagaimanapun, keinginan untuk berusaha ke arah memajukan diri dalam pembelajaran bahasa menuntut semangat atau keazaman yang kuat. Tidak semua pelajar akan bertindak untuk merealisasikan tujuan ini secara sukarela. Dalam hal ini, teori humanisme menjelaskan bahawa pelajar boleh dipupuk untuk belajar melalui keinginan sendiri berdasarkan keperluan untuk mencapai hasrat diri (Ee, 2002). Dengan mengetahui keperluan pembelajaran bahasa kepada diri individu, 
pelajar boleh dipupuk untuk menjadi lebih bertanggungjawab terhadap pembelajarannya. Selain itu, perubahan tingkah laku positif juga dapat dipupuk melalui rangsangan motivasi yang boleh membentuk kesedaran diri untuk belajar. Hal ini demikian kerana motivasi merupakan salah satu aspek yang dapat membentuk kepercayaan positif dalam diri pelajar.

Horwitz (1988), Banya dan Cheng (1997), Huang (2006) serta Javadi, Jahandar, dan Khodabandehlou (2012) menyatakan bahawa kepercayaan tertentu yang terbentuk dapat mempengaruhi hasil pembelajaran bahasa pelajar. Walau bagaimanapun, kebanyakan guru dan pelajar tidak menyedari bahawa faktor kepercayaan ini dapat mempengaruhi perkembangan hasil pembelajaran bahasa pelajar (Javadi et al., 2012). Keadaan ini boleh berlaku disebabkan kepercayaan individu sama ada positif mahupun negatif dapat mempengaruhi sikap dan usaha mereka dalam pembelajaran bahasa. Sebagaimana yang dinyatakan oleh Wenden (1986), kepercayaan boleh mendorong seseorang individu menetapkan tindakan sewajarnya untuk maju dalam pembelajaran bahasa sama ada secara sedar atau pun tidak. Pernyataan ini menunjukkan bahawa kepercayaan dapat mempengaruhi motivasi pelajar dalam pembelajaran bahasa tanpa mereka sedari. Justeru, hasil kajian ini diharapkan dapat membantu guru memahami pola kepercayaan pelajar serta menyemai kepercayaan positif dalam diri pelajar untuk mencapai hasil pembelajaran yang lebih memberangsangkan.

Bidang kajian kepercayaan terhadap pembelajaran bahasa ini mula dipelopori oleh Horwitz (1987). Kepercayaan seseorang pelajar terhadap pembelajaran bahasa kedua atau bahasa asing bergantung kepada asas tertentu yang mengakibatkan persepsi atau tanggapan tertentu terbentuk dalam diri. Horwitz (1987, 1988) mengetengahkan konsep pembentukan kepercayaan ini berdasarkan lima konstruk iaitu a) kesukaran dalam pembelajaran bahasa, b) kebolehan semula jadi dalam pembelajaran bahasa, c) kebiasaan dalam pembelajaran bahasa, d) strategi pembelajaran dan komunikasi serta e) motivasi dan harapan. Lima konstruk ini dikaitkan dengan pelbagai isu kepercayaan yang berlaku dalam pembelajaran bahasa sebagaimana dinyatakan pada instrumen Belief about Language Learning Inventory (BALLI, 1987, 1988).

Dalam kajian Jafari dan Shokrpour (2012), soal selidik Belief about Language Learning Inventory (BALLI) oleh Horwitz (1987) versi bahasa Parsi digunakan untuk mengenal pasti kepercayaan pelajar terhadap pembelajaran bahasa Inggeris sebagai bahasa asing. Kajian tersebut melibatkan 80 orang pelajar universiti di Iran. Hasil analisis deskriptif pada lima konstruk kepercayaan utama menunjukkan jenis kepercayaan yang paling tinggi ditemui ialah motivasi dan harapan, diikuti oleh strategi pembelajaran dan komunikasi, kesukaran dalam pembelajaran bahasa, kebiasaan dalam pembelajaran bahasa, dan kebolehan semula jadi mempelajari bahasa asing. Dapatan yang sama turut ditemui dalam kajian Bagherzadeh (2012) yang turut membuktikan bahawa nilai min kepercayaan yang paling tinggi dalam kalangan pelajar kajiannya adalah pada konstruk motivasi dan harapan, manakala nilai min kepercayaan yang paling rendah adalah pada kebolehan semula jadi dalam pembelajaran bahasa.

Tercanlioglu (2005) dan Mokhtari (2007) juga turut berkongsi dapatan yang sama pada nilai min konstruk kepercayaan tertinggi pada motivasi dan harapan 
sebagaimana dua kajian yang dinyatakan sebelumnya. Walau bagaimanapun, nilai min pola kepercayaan terendah yang diperoleh oleh kedua-dua kajian ini adalah berbeza daripada kajian sebelumnya iaitu pada pola kesukaran dalam pembelajaran bahasa. Dapatan kajian Tercanlioglu (2005) dan Mokhtari (2007) ini menunjukkan bahawa pelajar dalam kajian mereka mempunyai kepercayaan positif dalam pembelajaran bahasa. Hal ini demikian kerana mereka didapati lebih bermotivasi untuk belajar bahasa tanpa mengendahkan kesukaran yang bakal dihadapi dalam proses pembelajaran tersebut.

Kajian Sioson (2011) berhubung strategi pembelajaran bahasa, kepercayaan dan kebimbangan bahasa dalam kalangan pelajar bahasa Inggeris sebagai bahasa asing di Filipina pula mendapati hasil yang sebaliknya iaitu nilai min konstruk kepercayaan yang paling tinggi adalah pada kesukaran dalam pembelajaran bahasa, manakala nilai min konstruk kepercayaan yang paling rendah terletak pada motivasi dan harapan. Bentuk kepercayaan pelajar bagi kajian Sioson (2011) ini dilihat sebagai negatif kerana pelajar lebih merasakan pembelajaran bahasa itu susah dan bukannya lebih bermotivasi untuk memajukan diri dengan meletakkan harapan tertentu dalam pembelajaran bahasa.

Rumusan yang dapat dibuat berdasarkan kelima-lima kajian kepercayaan pelajar ini ialah bentuk kepercayaan pelajar dalam mempelajari bahasa kedua atau bahasa asing dapat dibahagikan kepada dua keadaan sama ada positif atau negatif. Pelajar yang positif terhadap pembelajaran bahasa mempunyai kepercayaan yang lebih tinggi pada konstruk motivasi dan harapan (seperti kajian Bagherzadeh, 2012; Jafari \& Shokrpour, 2012; Mokhtari, 2007; Tercanlioglu, 2005) sedangkan pelajar yang negatif terhadap pembelajaran bahasa pula meletakkan kepercayaan yang tinggi pada konstruk kesukaran dalam pembelajaran bahasa (seperti kajian Sioson, 2011). Memandangkan bentuk kepercayaan pelajar ini mudah berubah-ubah dari semasa ke semasa, maka perubahannya dapat memberi kesan kepada perkembangan tahap pembelajaran bahasa yang semakin menaik atau menurun (Akbari \& Youran, 2013). Penerokaan bidang kajian kepercayaan terhadap pembelajaran bahasa Arab ini diharapkan dapat memberi maklumat awal mengenai bentuk kepercayaan pelajar di peringkat menengah. Dengan itu, objektif kajian ini dijalankan adalah untuk:

1. Mengenal pasti tahap kepercayaan pelajar terhadap pembelajaran bahasa Arab secara keseluruhan dan berdasarkan konstruk.

2. Mengenal pasti jenis dan tahap kepercayaan pelajar terhadap pembelajaran bahasa Arab berdasarkan item.

\section{Metodologi Kajian}

Kajian tinjauan secara keratan rentas ini melibatkan 350 orang responden yang terdiri daripada 175 pelajar lelaki dan 175 pelajar perempuan. Mereka merupakan pelajar tingkatan empat dari 12 buah sekolah menengah agama di sekitar Kedah. Instrumen soal selidik pula digunakan untuk memudahkan pengumpulan data daripada sampel yang ramai. Soal selidik yang dihasilkan oleh Horwitz $(1987,1988)$ iaitu BALLI diadaptasi dan diubahsuai mengikut kesesuaian kajian pembelajaran bahasa Arab sebagai bahasa kedua. Horwitz (1988) menyatakan tujuan inventori 
BALLI tersebut dibina adalah untuk mengenal pasti pendapat pelajar yang pelbagai berhubung isu-isu yang sering timbul dalam pembelajaran bahasa. Inventori BALLI ini telah siap diterjemahkan daripada bahasa Inggeris ke bahasa Melayu dengan bantuan Institut Terjemahan dan Buku Malaysia pada 16 Mei 2014.

Pada mulanya, soal selidik ini mengandungi 34 item. Sebanyak 33 item hasil adaptasi daripada Horwitz (1988) dan satu item tambahan diadaptasi daripada Horwitz (1987). Penambahan satu item ini dilakukan memandangkan kesesuaiannya dengan konteks perbincangan konstruk penggunaan strategi dan komunikasi. Item tersebut ialah "Struktur bahasa Arab adalah berbeza daripada bahasa Melayu". Selepas penilaian pakar, jumlah item keseluruhan soal selidik ini ialah 35 item. Penambahbaikan dan ubah suai item dilakukan mengikut saranan yang dikemukakan oleh pakar. Seterusnya, hasil keputusan Alfa Cronbach pula mengakibatkan beberapa item digugurkan daripada soal selidik kepercayaan ini. Akhirnya, soal selidik ini terdiri daripada 28 item pernyataan sahaja.

Item soal selidik kepercayaan ini diklasifikasikan kepada lima konstruk kepercayaan utama sebagaimana inventori asal BALLI (Horwitz, 1988). Lima konstruk kepercayaan tersebut ialah kesukaran dalam pembelajaran bahasa, kebolehan semula jadi dalam pembelajaran bahasa, kebiasaan dalam pembelajaran bahasa, strategi pembelajaran dan komunikasi serta motivasi dan harapan. Secara keseluruhannya, nilai pekali kebolehpercayaan untuk instrumen kepercayaan ini ialah 0.837. Nilai korelasi pekali Alfa Cronbach ini diterima oleh para sarjana (Fraenkel \& Wallen, 1990; Mohd. Majid, 1998; Muijs, 2004).

Bagi penilaian pernyataan item soalan 1-28, penilaiannya adalah berdasarkan tahap persetujuan pelajar yang bermula dengan skala nombor satu sehingga lima; (1) sangat tidak setuju, (2) tidak setuju, (3) tidak pasti, (4) setuju dan (5) sangat setuju. Data kajian ini hanya melibatkan analisis deskriptif untuk mengenal pasti jenis dan tahap kepercayaan pelajar dengan merujuk kepada nilai min dan sisihan piawai. Tahap kepercayaan pelajar pula dinilai berdasarkan interpretasi skor min skala likert lima mata oleh Oxford (1990). Dengan itu, skor min kepercayaan ini boleh dikelaskan kepada tiga tahap iaitu tinggi (antara 3.5 hingga 5.0), sederhana (antara 2.5 hingga 3.4 ) dan rendah (antara 1.0 hingga 2.4).

\section{Dapatan Kajian}

\section{Kepercayaan Pelajar Secara Keseluruhan dan Berdasarkan Konstruk}

Dengan merujuk kepada Jadual 1, tahap kepercayaan pelajar terhadap pembelajaran bahasa Arab secara keseluruhan dan berdasarkan lima konstruk kepercayaan utama dikemukakan. Dapatan menunjukkan tahap kepercayaan pelajar sekolah menengah agama secara keseluruhan (28 item) adalah tinggi $(M=3.76, S P=0.37)$. Tahap kepercayaan kelima-lima konstruk kepercayaan utama ini juga adalah tinggi. Lima konstruk kepercayaan pelajar terhadap pembelajaran bahasa Arab ini ialah a) kesukaran dalam pembelajaran bahasa, b) kebolehan semula jadi, c) kebiasaan dalam pembelajaran bahasa, d) strategi pembelajaran dan komunikasi serta e) motivasi dan harapan. 
Nilai min kepercayaan utama yang paling tinggi ialah motivasi dan harapan $(M=4.03, S P=0.57)$, diikuti oleh empat konstruk kepercayaan utama yang lain mengikut susunan tertinggi, iaitu kesukaran dalam pembelajaran bahasa ( $M=3.86$, $\mathrm{SP}=0.50)$, kebiasaan dalam pembelajaran bahasa $(\mathrm{M}=3.84, \mathrm{SP}=0.52)$, strategi pembelajaran dan komunikasi $(\mathrm{M}=3.62, \mathrm{SP}=0.49)$, dan kebolehan semula jadi ( $\mathrm{M}=$ $3.61, \mathrm{SP}=0.44)$. Susunan tahap kepercayaan berdasarkan konstruk kumpulan utama ini dapat diperhatikan dalam Jadual 1 mengikut susunan tertinggi kepada terendah.

Jadual 1

Kepercayaan terhadap pembelajaran bahasa Arab berdasarkan konstruk kumpulan utama mengikut susunan menurun ( $N=350)$

\begin{tabular}{lccc}
\hline \multicolumn{1}{c}{ Kepercayaan utama } & Min & SP & Tahap \\
\hline $\begin{array}{l}\text { Motivasi dan harapan } \\
\begin{array}{l}\text { Kesukaran dalam pembelajaran } \\
\text { bahasa }\end{array}\end{array}$ & 4.03 & 0.57 & Tinggi \\
$\begin{array}{l}\text { Kebiasaan dalam pembelajaran } \\
\text { bahasa }\end{array}$ & 3.86 & 0.50 & Tinggi \\
$\begin{array}{l}\text { Strategi pembelajaran dan } \\
\text { komunikasi }\end{array}$ & 3.84 & 0.52 & Tinggi \\
$\begin{array}{l}\text { Kebolehan semula jadi } \\
\text { Keseluruhan }\end{array}$ & 3.62 & 0.49 & Tinggi \\
\hline \multicolumn{4}{l}{} \\
\hline
\end{tabular}

Selain itu, carta bar pada Rajah 1 turut dikemukakan bagi melihat perbezaan nilai skor min bagi kelima-lima konstruk utama kepercayaan terhadap pembelajaran bahasa Arab. Susunan skor min ini dimulakan dengan konstruk kepercayaan tertinggi kepada terendah.

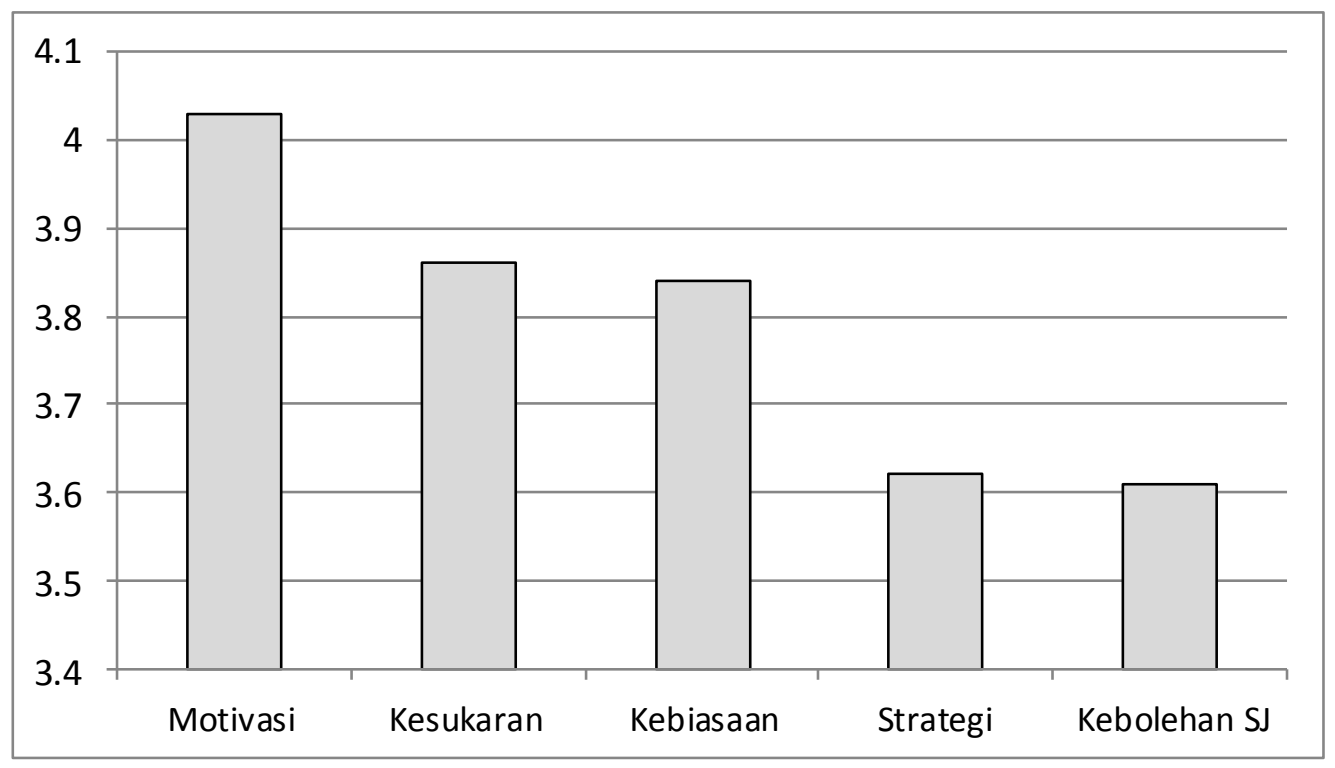

Rajah 1. Carta bar nilai min lima konstruk kepercayaan utama 


\section{Kepercayaan Pelajar Berdasarkan Item}

\section{kesukaran dalam pembelajaran bahasa.}

Jadual 2 pula menyenaraikan empat item kepercayaan berdasarkan kesukaran dalam pembelajaran bahasa (KA1 hingga KA4). Tahap kepercayaan pelajar bagi empat item ini terbahagi kepada dua, iaitu tahap kepercayaan tinggi dan tahap kepercayaan sederhana. Tahap kepercayaan tinggi pelajar merujuk kepada tiga item, iaitu KA1 $(M=4.09, \mathrm{SP}=0.84), \mathrm{KA} 2(\mathrm{M}=4.01, \mathrm{SP}=0.81)$ dan $\mathrm{KA4}(\mathrm{M}=4.05, \mathrm{SP}=0.91)$. Seterusnya, item KA3 $(M=3.28, S P=0.88)$ pula menunjukkan tahap kepercayaan yang sederhana. Kesimpulannya, susunan item kepercayaan dalam bahagian ini boleh disusun mengikut susunan tertinggi, iaitu tiga item (KA1, KA4, dan KA2) merujuk kepada tahap kepercayaan yang tinggi, manakala baki satu item (KA3) pula merujuk kepada tahap kepercayaan yang sederhana.

Jadual 2

Min dan sisihan piawai kesukaran dalam pembelajaran bahasa $(N=350)$

\begin{tabular}{|c|c|c|c|c|}
\hline No Item & Kepercayaan & Min & SP & Tahap \\
\hline KA1 & $\begin{array}{l}\text {-Sesetengah bahasa lebih mudah } \\
\text { dipelajari berbanding bahasa } \\
\text { lain. }\end{array}$ & 4.09 & 0.84 & Tinggi \\
\hline KA2 & $\begin{array}{l}\text { !-Saya percaya saya akan berjaya } \\
\text { bertutur dalam bahasa Arab } \\
\text { dengan sangat baik pada } \\
\text { akhirnya. }\end{array}$ & 4.01 & 0.81 & Tinggi \\
\hline KA3 & $\begin{array}{l}\text { i-Bertutur dalam bahasa Arab } \\
\text { lebih mudah daripada } \\
\text { memahami apa yang } \\
\text { diperkatakan oleh pihak lain. }\end{array}$ & 3.28 & 0.88 & Sederhana \\
\hline KA4 & $\begin{array}{clc}\text { l-Membaca } & \text { lebih } & \text { mudah } \\
\text { berbanding } & \text { bertutur } & \text { dalam } \\
\text { bahasa Arab. } & & \end{array}$ & 4.05 & 0.91 & Tinggi \\
\hline
\end{tabular}

kebolehan semula jadi.

Dalam Jadual 3, tahap kepercayaan bagi lapan item dalam kategori kebolehan semula jadi (KB5 hingga KB12) boleh dikelaskan kepada tiga tahap kepercayaan, iaitu tinggi, sederhana dan rendah. Lima item menunjukkan tahap kepercayaan yang tinggi iaitu $\mathrm{KB} 5(\mathrm{M}=3.95, \mathrm{SP}=0.92), \mathrm{KB} 6(\mathrm{M}=3.83, \mathrm{SP}=1.03), \mathrm{KB} 10$ $(\mathrm{M}=4.23, \mathrm{SP}=0.85), \mathrm{KB} 11(\mathrm{M}=4.11, \mathrm{SP}=0.87)$ dan $\mathrm{KB} 12(\mathrm{M}=4.41, \mathrm{SP}=0.83)$. Tahap kepercayaan yang sederhana pula merujuk kepada dua item kepercayaan, iaitu KB7 $(\mathrm{M}=3.24, \mathrm{SP}=0.91)$ dan $\mathrm{KB} 8(\mathrm{M}=2.82, \mathrm{SP}=1.22)$. Akhirnya, tahap kepercayaan yang rendah pula diwakili oleh satu item, iaitu KB9 $(M=2.24, S P=1.16)$. Keseluruhannya, susunan item kepercayaan dalam kategori ini boleh disusun mengikut susunan tertinggi, iaitu dimulakan dengan lima item kepercayaan pada tahap tinggi (KB12, 
KB10, KB11, KB5, dan KB6), dua item kepercayaan pada tahap sederhana (KB7 dan KB8) dan satu item kepercayaan pada tahap rendah (KB9).

Jadual 3

Min dan sisihan piawai kebolehan semula jadi $(N=350)$

\begin{tabular}{|c|c|c|c|c|}
\hline No Item & Kepercayaan & Min & SP & Tahap \\
\hline KB5 & $\begin{array}{lr}\text { 5-Kanak-kanak lebih mudah } & \text { muk } \\
\text { untuk mempelajari } & \text { bahasa } \\
\text { Arab berbanding } & \text { orang } \\
\text { dewasa. }\end{array}$ & 3.95 & 0.92 & Tinggi \\
\hline KB6 & $\begin{array}{l}\text { 6-Sesetengah orang dilahirkan } \\
\text { dengan kebolehan istimewa } \\
\text { yang membantu mereka } \\
\text { mempelajari bahasa Arab. }\end{array}$ & 3.83 & 1.03 & Tinggi \\
\hline KB7 & $\begin{array}{lr}\text { 7-Seseorang } & \text { yang } \\
\text { sememangnya bertutur } \\
\text { dalam bahasa asing lebih } \\
\text { mudah untuk mempelajari } \\
\text { bahasa yang lain. }\end{array}$ & 3.24 & 0.91 & Sederhana \\
\hline KB8 & $\begin{array}{l}\text { 8-Perempuan dapat } \\
\text { mempelajari bahasa Arab } \\
\text { dengan lebih baik berbanding } \\
\text { lelaki. }\end{array}$ & 2.82 & 1.22 & Sederhana \\
\hline KB9 & $\begin{array}{l}\text { J-Orang yang bijak dalam } \\
\text { matematik dan sains tidak } \\
\text { bijak dalam mempelajari } \\
\text { bahasa Arab. }\end{array}$ & 2.24 & 1.16 & Rendah \\
\hline KB10 & $\begin{array}{l}\text { 10-Orang yang bertutur lebih } \\
\text { daripada satu bahasa dengan } \\
\text { baik adalah sangat pintar. }\end{array}$ & 4.23 & 0.85 & Tinggi \\
\hline KB11 & $\begin{array}{ll}\text { L1-Rakyat Malaysia boleh } & \text { mempelajari bahasa } \\
\text { mabab } \\
\text { dengan baik. }\end{array}$ & 4.11 & 0.87 & Tinggi \\
\hline KB12 & $\begin{array}{l}\text { 12-Semua orang boleh belajar } \\
\text { untuk bertutur dalam bahasa } \\
\text { Arab. }\end{array}$ & 4.41 & 0.83 & Tinggi \\
\hline
\end{tabular}

kebiasaan dalam pembelajaran bahasa.

Berdasarkan konstruk kebiasaan dalam pembelajaran bahasa dalam Jadual 4 pula, analisis deskriptif menunjukkan enam item kepercayaan (KC13 hingga KC18) dalam kategori ini boleh dikategorikan kepada tahap kepercayaan yang tinggi kecuali pada satu item iaitu $\mathrm{KC13}(\mathrm{M}=3.31, \mathrm{SP}=0.98)$ yang merujuk kepada tahap kepercayaan sederhana. Lima item kebiasaan dalam pembelajaran bahasa yang berada pada tahap tinggi pula ialah $\mathrm{KC1} 14(\mathrm{M}=3.86, \mathrm{SP}=0.82), \mathrm{KC15}(\mathrm{M}=4.17, \mathrm{SP}=$ $0.84), K C 16(M=3.99, S P=0.79), K C 17(M=3.78, S P=0.87)$, dan $K C 18(M=3.93, S P=$ 
0.90). Rumusannya, susunan item kepercayaan dalam bahagian ini boleh disenaraikan mengikut susunan tertinggi kepada terendah seperti lima item kepercayaan tahap tinggi (KC15, KC16, KC18, KC14, KC17) dan satu item kepercayaan tahap sederhana (KC13).

Jadual 4

Min dan sisihan piawai kebiasaan dalam pembelajaran bahasa $(N=350)$

\begin{tabular}{|c|c|c|c|c|}
\hline No Item & Kepercayaan & Min & SP & Tahap \\
\hline KC13 & $\begin{array}{l}\text { KC13-Saya perlu tahu budaya } \\
\text { Arab untuk bertutur dalam } \\
\text { bahasa Arab. }\end{array}$ & 3.31 & 0.98 & Sederhana \\
\hline KC14 & $\begin{array}{l}\text { KC14-Sebahagian } \\
\text { pembelajaran bahasa Arab } \\
\text { adalah berkenaan dengan } \\
\text { pembelajaran kosa kata } \\
\text { baharu yang banyak. }\end{array}$ & 3.86 & 0.82 & Tinggi \\
\hline KC15 & 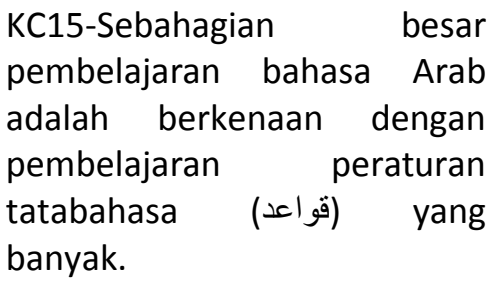 & 4.17 & 0.84 & Tinggi \\
\hline KC16 & $\begin{array}{l}\text { KC16-Mempelajari bahasa } \\
\text { Arab berbeza daripada } \\
\text { mempelajari mata pelajaran } \\
\text { yang lain. }\end{array}$ & 3.99 & 0.79 & Tinggi \\
\hline KC17 & $\begin{array}{l}\text { KC17-Sebahagian } \\
\text { pembelajaran bahasa Arab } \\
\text { adalah berkenaan dengan } \\
\text { penterjemahan. }\end{array}$ & 3.78 & 0.87 & Tinggi \\
\hline KC18 & $\begin{array}{l}\text { KC18-Struktur bahasa Arab } \\
\text { adalah berbeza daripada } \\
\text { bahasa Melayu. }\end{array}$ & 3.93 & 0.9 & Tinggi \\
\hline
\end{tabular}

strategi pembelajaran dan komunikasi.

Konstruk strategi pembelajaran dan komunikasi pada Jadual 5 pula merujuk kepada enam item kepercayaan (KD19 hingga KD24). Tahap kepercayaan pelajar dalam bahagian ini boleh dibahagikan kepada dua, iaitu tinggi dan sederhana. Tiga item yang berada pada tahap kepercayaan yang tinggi ini ialah $\mathrm{KD} 19(\mathrm{M}=3.91, \mathrm{SP}=$ 0.90), KD21 ( $M=4.35, S P=0.78)$, dan KD24 ( $M=3.71, S P=0.98)$. Baki tiga item kepercayaan dalam bahagian ini pula menggambarkan tahap kepercayaan yang sederhana iaitu KD20 ( $M=3.29, \mathrm{SP}=0.91), \mathrm{KD} 22(\mathrm{M}=3.20, \mathrm{SP}=1.17)$, dan KD23 (M= $3.25, \mathrm{SP}=0.95)$. Kesimpulan yang dapat dibuat dalam bahagian ini ialah tiga item kepercayaan (KD21, KD19, dan KD24) berada pada tahap tinggi, manakala baki tiga item kepercayaan lagi (KD20, KD23, dan KD22) berada pada tahap sederhana. 
Jadual 05

Min dan sisihan piawai strategi pembelajaran dan komunikasi $(N=350)$

\begin{tabular}{|c|c|c|c|c|}
\hline No Item & Kepercayaan & Min & SP & Tahap \\
\hline KD19 & $\begin{array}{l}\text { 9-Bertutur dalam bahasa Arab } \\
\text { dengan dialek/loghat yang } \\
\text { sangat baik adalah penting. }\end{array}$ & 3.91 & 0.90 & Tinggi \\
\hline KD20 & $\begin{array}{l}\text { 0-Jika saya terdengar seseorang } \\
\text { bertutur dalam bahasa Arab, } \\
\text { saya akan pergi kepadanya } \\
\text { supaya saya dapat berlatih } \\
\text { bertutur bahasa ini. }\end{array}$ & 3.29 & 0.91 & Sederhana \\
\hline KD21 & $\begin{array}{l}\text { 1-Mengulang dan banyak } \\
\text { berlatih dalam pembelajaran } \\
\text { bahasa Arab adalah penting. }\end{array}$ & 4.35 & 0.78 & Tinggi \\
\hline KD22 & $\begin{array}{l}\text { 2-Jika saya membiarkan diri } \\
\text { melakukan kesilapan pada } \\
\text { peringkat permulaan, sukar } \\
\text { untuk saya memperbaikinya } \\
\text { kemudian. }\end{array}$ & 3.2 & 1.17 & Sederhana \\
\hline KD23 & $\begin{array}{l}\text { 3-Berlatih di makmal bahasa } \\
\text { adalah penting. }\end{array}$ & 3.25 & 0.95 & Sederhana \\
\hline KD24 & $\begin{array}{lr}\text { 4-Berlatih } & \begin{array}{l}\text { dengan } \\
\text { menggunakan }\end{array} \\
\text { audio- visualatan } \\
\text { pandang-dengar seperti video) } \\
\text { adalah penting. }\end{array}$ & 3.71 & 0.98 & Tinggi \\
\hline
\end{tabular}

motivasi dan harapan.

Dalam konstruk motivasi dan harapan pada Jadual 6 pula, empat item kepercayaan (KE25 hingga KE28) dalam kategori ini berada pada tahap tinggi. Empat item kepercayaan pada tahap tinggi ini ialah KE25 ( $N=4.39, S P=0.77), K E 26$ ( $N=$ 4.00, $\mathrm{SP}=0.86), \mathrm{KE} 27(\mathrm{~N}=3.70, \mathrm{SP}=0.96)$ dan KE28 $(\mathrm{N}=4.04, \mathrm{SP}=0.91)$. Susunan keempat-empat item kepercayaan dalam kategori motivasi dan harapan ini mengikut item kepercayaan tertinggi ialah KE25, KE28, KE26 dan KE27. 
Jadual 6

Min dan sisihan piawai motivasi dan harapan $(N=350)$

\begin{tabular}{|c|c|c|c|c|}
\hline No Item & Kepercayaan & Min & SP & Tahap \\
\hline KE25 & $\begin{array}{l}\text { KE25-Jika saya dapat bertutur } \\
\text { dalam bahasa Arab dengan } \\
\text { sangat baik, saya akan } \\
\text { mempunyai banyak peluang } \\
\text { untuk menggunakannya. }\end{array}$ & 4.39 & 0.77 & Tinggi \\
\hline KE26 & $\begin{array}{l}\text { KE26-Kemampuan bertutur } \\
\text { dalam bahasa Arab dapat } \\
\text { memberi peluang pekerjaan } \\
\text { yang lebih cerah kepada saya. }\end{array}$ & 4.00 & 0.86 & Tinggi \\
\hline KE27 & 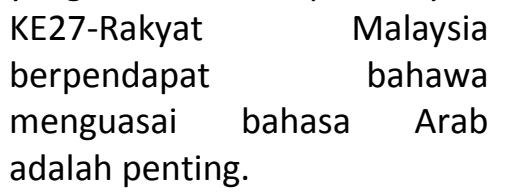 & 3.70 & 0.96 & Tinggi \\
\hline KE28 & $\begin{array}{l}\text { KE28-Saya ingin belajar bahasa } \\
\text { Arab supaya dapat mengenali } \\
\text { penuturnya dengan lebih baik. }\end{array}$ & 4.04 & 0.91 & Tinggi \\
\hline
\end{tabular}

\section{Perbincangan Kajian}

Tahap kepercayaan pelajar secara keseluruhan terhadap pembelajaran bahasa Arab adalah tinggi ( $M=3.76)$. Dapatan ini adalah selari dengan kajian Li (2010) terhadap 214 pelajar kolej di China yang turut mendapati tahap keseluruhan kepercayaan responden kajian beliau adalah tinggi. Kepercayaan yang tinggi ini menunjukkan bahawa pelajar secara keseluruhannya mempunyai kepercayaan yang positif terhadap pembelajaran bahasa. Kepercayaan positif yang tinggi ini juga boleh mendorong pelajar untuk lebih maju ke hadapan dan tabah menghadapi kesukaran dalam pembelajaran.

Tahap kepercayaan pelajar terhadap pembelajaran bahasa Arab berdasarkan konstruk juga adalah tinggi. Susunan kategori kepercayaan tertinggi bermula dengan motivasi dan harapan, diikuti oleh empat kepercayaan yang lain mengikut susunan tertinggi kepada terendah iaitu kesukaran dalam pembelajaran bahasa, kebiasaan dalam pembelajaran bahasa, strategi pembelajaran dan komunikasi, dan kebolehan semula jadi. Perbincangan lanjut berhubung kepercayaan pelajar berdasarkan konstruk ini dibincangkan dengan lebih terperinci dalam sub-tajuk berikutnya.

\section{Motivasi dan Harapan}

Pelajar dalam kajian ini didapati mempunyai tahap kepercayaan yang paling tinggi pada konstruk motivasi dan harapan. Kepercayaan yang positif ini adalah selari dengan beberapa kajian yang lain seperti kajian Tercanlioglu (2005), Mokhtari (2007), Bagherzadeh (2012) serta Jafari dan Shokrpour (2012). Tahap kepercayaan yang paling tinggi pada konstruk motivasi dan harapan ini menunjukkan pelajar 
secara keseluruhannya mempunyai dorongan positif melalui motivasi intrinsik untuk berjaya dalam pembelajaran bahasa Arab. Semangat ingin tahu dalam pembelajaran dapat mendorong pelajar menumpukan perhatian kepada pelaksanaan tindakan yang sesuai (Brophy, 2004; Schunk, 2001), meningkatkan keyakinan diri dan mengawasi perkembangan pembelajaran yang dijangkakan (Schunk, 2001).

Menurut Eccles dan Wigfield (2002), antara faktor yang membantu pembentukan motivasi intrinsik ini ialah minat, semangat ingin tahu serta berusaha untuk kecekapan dan penguasaan. Pelajar kajian ini mungkin mempunyai motivasi yang tinggi disebabkan rangsangan dan pendekatan guru yang menerima pelajar tanpa syarat dalam pembelajaran diamalkan sebagaimana yang ditekankan oleh teori pembelajaran humanisme menerusi prinsip pembelajaran Rogers (Ee, 2002; Rashid, Boon, \& Syed Ahmad, 2009).

Empat item kepercayaan dalam kategori motivasi dan harapan ini turut berada pada tahap kepercayaan yang tinggi. Majoriti pelajar didapati mempunyai motivasi yang tinggi untuk mempelajari dan bertutur dalam bahasa Arab dengan baik supaya "memperoleh banyak peluang menggunakannya", "mengenali penutur Arab" dan "mendapat peluang pekerjaan yang baik". Seseorang yang mempelajari sesuatu bahasa pasti berhasrat untuk menuturkan bahasa tersebut. Penguasaan bahasa yang turut boleh dinilai berdasarkan kebolehan seseorang individu menuturkan bahasa Arab mungkin menyebabkan pelajar bermotivasi untuk mempelajari dan menguasai kemahiran bertutur bahasa ini dengan lebih baik.

Selain itu, lebih daripada separuh pelajar dalam kajian ini merasakan bahawa "pembelajaran bahasa Arab penting untuk dikuasai oleh rakyat Malaysia". Hal ini demikian mungkin kerana bahasa Arab merupakan bahasa yang digunakan dalam ibadah seharian semasa solat, berdoa, berzikir dan membaca al-Quran atau Hadis. Justeru, memahami bahasa Arab ini dianggap penting kerana setiap Muslim menggunakannya dalam kehidupan seharian.

\section{Kesukaran dalam Pembelajaran Bahasa}

Kategori kepercayaan kedua tertinggi pula diwakili oleh kesukaran dalam pembelajaran bahasa. Apabila pelajar mempunyai kepercayaan yang tinggi dalam kategori kesukaran dalam pembelajaran bahasa, ini menunjukkan pelajar mempunyai perspektif yang positif terhadap kesukaran yang dihadapi sepanjang proses pembelajaran dengan beranggapan tidak semua sukatan pembelajaran sukar ditangani. Persepsi yang positif ini menjadikan pelajar lebih matang menghadapi pelbagai kesukaran dalam pembelajaran. Berbeza pula dengan kajian yang melaporkan kepercayaan terendah pada kesukaran dalam pembelajaran bahasa (Mokhtari, 2007; Tercanlioglu, 2005). Sekiranya kepercayaan terendah berada pada kategori kesukaran, ini menunjukkan bahawa pelajar merasakan bahawa pembelajaran bahasa sukar ditangani.

Walau bagaimanapun, kebimbangan yang melampau terhadap kesukaran dalam pembelajaran bahasa tidak berlaku dalam kajian. Hal ini demikian kerana pelajar dalam kajian ini mempamerkan kepercayaan yang tinggi pada tiga pernyataan item dan kepercayaan yang sederhana pada satu pernyataan item dalam kategori kesukaran. Pernyataan tersebut menunjukkan bahawa pelajar merasakan 
bahawa pembelajaran bahasa mudah ditangani dalam keadaan dan kemahiran tertentu. Tiga pernyataan item yang menunjukkan kepercayaan yang tinggi ialah "anggapan bahawa tidak semua bahasa sukar ditangani", "membaca lebih mudah daripada bertutur dalam bahasa Arab", dan "berkeyakinan dapat bertutur dalam bahasa Arab dengan sangat baik". Ketiga-tiga pernyataan ini dapat membuktikan bahawa pelajar positif terhadap proses pembelajaran bahasa yang tidak selalunya sukar ditangani.

Selain itu, kemahiran berbahasa tertentu seperti membaca dipercayai lebih mudah ditangani berbanding kemahiran bertutur. Kepercayaan ini mungkin disebabkan penerimaan input bahasa Arab di peringkat sekolah menengah yang menekankan proses membaca sehingga membolehkan kemahiran ini lebih mudah dilatih daripada mempraktikkan bahasa melalui pertuturan. Beberapa kajian membuktikan bahawa pelajar mengalami kesukaran dalam pertuturan bahasa Arab kerana kemahiran ini tidak dipraktikkan dengan kadar yang lebih kerap dalam pembelajaran bahasa (Aladdin, 2012; Abdul Pisal, 2012; Daud \& Abdul Pisal, 2014; Mohamad, 2009).

Walaupun demikian, pelajar dalam kajian ini tetap berkeyakinan mereka mampu untuk bertutur dalam bahasa Arab dengan sangat baik pada masa hadapan. Keyakinan yang positif ini mungkin terbentuk dalam diri pelajar disebabkan keinginan dan azam yang kuat untuk menguasai kemahiran ini pada masa hadapan. Kenyataan ini disokong oleh dapatan kajian yang menunjukkan majoriti pelajar iaitu sebanyak $87.7 \%$ dan $71.5 \%$ pelajar bermotivasi untuk menguasai kemahiran bertutur supaya berpeluang menggunakannya dan memperoleh peluang pekerjaan yang lebih baik.

Satu pernyataan item yang merujuk kepada kepercayaan yang sederhana dalam kategori kesukaran ini ialah "bertutur dalam bahasa Arab lebih mudah daripada memahami apa yang diperkatakan". Kepercayaan yang sederhana pada kebolehan bertutur menunjukkan bahawa kemahiran ini perlu kepada latihan yang berterusan. Kesukaran menguasai kemahiran bertutur jika dibandingkan dengan kemahiran mendengar mungkin disebabkan pelajar kurang berpeluang menggunakan bahasa Arab dalam situasi yang berbeza, manakala kemahiran mendengar pula lebih banyak digunakan semasa sesi pembelajaran bahasa Arab di dalam kelas untuk menerima maklumat pengajaran guru. Justeru, fokus pelajar pada kemahiran bertutur boleh dikatakan kurang dipraktikkan jika dibandingkan dengan kemahiran mendengar.

\section{Kebiasaan dalam Pembelajaran Bahasa}

Kebiasaan dalam pembelajaran bahasa pula merupakan kategori kepercayaan ketiga tertinggi. Perbezaan nilai min sebanyak 0.02 antara kategori kepercayaan kedua tertinggi (kesukaran) dan ketiga tertinggi (kebiasaan) ini menunjukkan tahap kepercayaan pelajar bagi kedua-dua kategori ini terlalu hampir. Dengan itu, dapat disimpulkan di sini bahawa kebiasaan pelajar dalam pembelajaran bahasa turut dipengaruhi oleh kepercayaan terhadap kesukaran dalam pembelajaran bahasa Arab. Sekiranya pelajar menghadapi kesukaran untuk menguasai aspek tertentu dalam pembelajaran bahasa misalnya, mereka pasti 
mempunyai keyakinan tersendiri berhubung aspek pembelajaran bahasa yang perlu dikuasai dan dibiasakan dalam pembelajaran seterusnya.

Enam item kepercayaan dalam kategori kebiasaan dalam pembelajaran bahasa ini merujuk kepada lima item kebiasaan yang berada pada tahap kepercayaan tinggi dan satu item kebiasaan pada tahap kepercayaan sederhana. Majoriti pelajar mempunyai pendirian yang sama pada lima pernyataan item kebiasaan yang perlu diberi lebih perhatian dalam proses pembelajaran bahasa Arab seperti pembelajaran "peraturan tatabahasa (قواعد)", "kosa kata baharu" dan "terjemahan" selain memahami "perbezaan pembelajaran subjek bahasa Arab berbanding mata pelajaran yang lain" serta "struktur bahasa Arab yang berbeza daripada bahasa Melayu".

Pembelajaran bahasa Arab yang berbeza daripada mata pelajaran lain mungkin disebabkan bahan pembelajarannya menggunakan bahasa yang berbeza selain terdapat pecahan tertentu pada skop pembelajaran bahasa yang meliputi aspek tatabahasa (nahu dan sorof), kemahiran berbahasa, linguistik dan literatur. Selain itu, struktur pembelajaran bahasa Arab yang berbeza daripada bahasa ibunda pelajar (bahasa Melayu), menyebabkan pelajar memberi perhatian yang lebih kepada pembelajaran peraturan tatabahasa (قواعد)", "kosa kata baharu" dan "terjemahan" dalam pembelajaran bahasa Arab. Penekanan kepada aspek tatabahasa yang lebih tinggi berbanding penguasaan kosa kata dan terjemahan mungkin disebabkan pelajar sering menghadapi kesukaran untuk membina ayat yang gramatis dalam bahasa Arab. Tambahan pula, tatabahasa Arab ini mempunyai keunikan tersendiri yang perlu dikuasai dengan sebaiknya kerana sedikit perubahan baris hukum I'rab sama ada marfu', mansub atau majrur dalam ayat boleh mengubah makna sesuatu ungkapan.

Baki satu item yang berada pada tahap kepercayaan sederhana iaitu "mengetahui budaya Arab untuk bertutur dalam bahasa Arab" menunjukkan bahawa pelajar tidak merasakan kebiasaan ini penting untuk menguasai kemahiran bertutur dalam bahasa Arab. Hal ini demikian mungkin kerana pelajar kurang didedahkan dengan suasana komunikasi penutur asli dalam kalangan orang Arab serta pelajar tidak mempunyai peluang untuk bertutur dalam bahasa Arab dengan penutur asli Arab itu sendiri. Peluang untuk bertutur dengan orang Arab di peringkat menengah adalah agak sukar jika dibandingkan dengan peringkat universiti yang lebih terdedah kepada pelajar luar dari negara yang berbeza. Justeru, tidak hairanlah kepercayaan ini berada pada tahap sederhana kerana pelajar tidak dibiasakan dengan pengetahuan budaya orang Arab dalam pembelajaran bahasa ini semasa di peringkat sekolah.

\section{Strategi Pembelajaran dan Komunikasi}

Kepercayaan berhubung kepentingan atau keberkesanan penggunaan sesuatu strategi pembelajaran dan komunikasi berada pada kedudukan kedua terendah. Perbezaan nilai min kepercayaan antara konstruk strategi (kedua terendah) dan konstruk kebolehan semula jadi (terendah) pada 0.01 mungkin disebabkan pelajar tidak menyedari kepentingan penggunaan strategi dan kebolehan semula jadi tertentu yang boleh dimanfaatkan untuk meningkatkan 
penguasaan bahasa Arab. Walau bagaimanapun, tahap kepercayaan pelajar berdasarkan faktor strategi ini adalah tinggi. Tiga item kepercayaan terhadap penggunaan strategi ini didapati berada pada tahap tinggi seperti kepentingan "pengulangan dan latihan yang banyak", "bertutur dengan dialek atau loghat yang sangat baik" dan "berlatih dengan menggunakan peralatan audio-visual".

Kepercayaan pelajar yang tinggi pada tiga item strategi pembelajaran dan komunikasi ini menunjukkan bahawa penggunaan strategi-strategi tersebut didapati dapat membantu perkembangan bahasa pelajar dengan lebih baik jika dimanfaatkan dengan sebaiknya. Pengulangan dan latihan misalnya dipercayai dapat memantapkan pengetahuan dan penguasaan kemahiran berbahasa Arab pelajar. Pernyataan ini seiring dengan teori behaviorisme yang menggambarkan bahawa penguasaan bahan pembelajaran boleh diperkukuhkan melalui pengulangan dan latihan yang banyak (Husin, 2010).

Bertutur dengan menggunakan makhraj huruf Arab yang betul pula mungkin dianggap penting kerana penggunaan strategi ini dapat memperbaiki mutu pertuturan pelajar untuk bercakap mengikut dialek atau lahjah Arab. Penggunaan peralatan audio-visual dalam pembelajaran bahasa juga dianggap penting kerana penggunaan bahan bantu belajar ini dapat membantu pelajar menyerap pelbagai maklumat bahasa dalam keadaan yang santai dan lebih menyeronokkan. Tayangan video misalnya, merupakan salah satu peralatan yang dapat digunakan untuk membantu pelajar memahami maklumat bahasa yang disampaikan melalui pergerakan gambar selain melalui bunyi.

Tiga item kepercayaan lain dalam kategori ini pula berada pada tahap sederhana seperti "berlatih bertutur dengan sesiapa yang sedang bertutur dalam bahasa Arab", "berlatih di makmal bahasa" dan "tidak membiarkan diri melakukan kesilapan pada peringkat permulaan". Kurang daripada $50 \%$ pelajar bersetuju mahupun sangat setuju dengan tiga item penggunaan strategi ini. Kebanyakan pelajar berada antara setuju dan tidak setuju dengan strategi melibatkan diri dalam perbualan dan berlatih di makmal bahasa. Kedua-dua pandangan ini mungkin disebabkan pelajar tidak selalu atau tidak berpeluang menggunakan strategi tersebut dalam pembelajaran bahasa Arab. Kepentingan menggunakan makmal bahasa yang berada pada tahap kepercayaan yang sederhana ini mungkin disebabkan pelajar sendiri tidak pernah menggunakan kemudahan tersebut di sekolah masing-masing. Hal ini terbukti benar apabila kebanyakan pelajar tidak mengetahui fungsi makmal bahasa dan menyatakan bahawa kemudahan tersebut tidak tersedia di sekolah mereka.

Sebanyak $41.2 \%$ pelajar didapati bersetuju mahupun sangat setuju untuk tidak melakukan kesilapan pada peringkat permulaan kerana perbuatan ini akan menyukarkan mereka memperbaiki kesilapan selepas itu. Kepercayaan yang berada pada tahap sederhana ini menunjukkan bahawa mengelakkan diri melakukan kesalahan pada peringkat permulaan tidak selalunya menjadi keutamaan semua pelajar. Pelajar cemerlang bahasa misalnya dikatakan sebagai individu yang berani melakukan kesilapan semata-mata untuk belajar (Rubin, 1975). Penggunaan strategi ini boleh dikaitkan penggunaannya dengan kemahiran bertutur. Kesilapan dalam pembelajaran bahasa biasanya tidak menjadi penghalang kepada pelajar cemerlang untuk meneruskan pertuturan dalam bahasa sasaran. 


\section{Kebolehan Semula Jadi}

Tahap kepercayaan terendah dalam kajian ini pula diwakili oleh konstruk kebolehan semula jadi. Dapatan ini adalah selari dengan kajian Bagherzadeh (2012) serta Jafari dan Shokrpour (2012). Kepercayaan semula jadi yang berada pada kedudukan terendah ini mungkin disebabkan oleh keyakinan pelajar bahawa setiap individu mampu mempelajari bahasa tanpa mengendahkan keistimewaan tertentu yang dimiliki oleh pihak lain. Oleh itu, kategori kebolehan semula jadi ini boleh dikatakan tidak banyak memberi kesan kepada kepercayaan pelajar.

Tahap kepercayaan lapan item dalam kategori kebolehan semula jadi ini boleh dikelaskan kepada tiga tahap iaitu tinggi (lima item), sederhana (dua item) dan rendah (satu item). Lima item kebolehan semula jadi yang berada pada tahap kepercayaan tinggi ialah "semua orang boleh belajar untuk bertutur dalam bahasa Arab", "orang yang bertutur lebih daripada satu bahasa dengan baik adalah sangat pintar", "rakyat Malaysia boleh mempelajari bahasa Arab dengan baik", "kanakkanak lebih mudah mempelajari bahasa Arab berbanding orang dewasa" dan "sesetengah orang dilahirkan dengan kebolehan istimewa yang membantu mereka mempelajari bahasa Arab". Secara umumnya, item kepercayaan yang berada pada tahap tinggi ini merupakan andaian positif yang meyakini bahawa penguasaan bahasa Arab boleh dikuasai oleh sesiapa sahaja meskipun sesetengah individu dikatakan mempunyai kebolehan tertentu dengan menguasai lebih banyak bahasa dan kanak-kanak lebih mudah mempelajari bahasa.

Andaian bahawa kanak-kanak lebih mudah menyerap input bahasa mungkin boleh dikaitkan dengan penyerapan kosa kata dengan kadar yang lebih banyak pada permulaan pembelajaran. Walau bagaimanapun, perbandingan ini tidak sesuai jika dibandingkan dengan tahap pembelajaran yang lebih sukar dengan pendedahan input bahasa melalui sukatan pelajaran nahu dan sorof. Hal ini demikian kerana kematangan usia pelajar dewasa dapat mendahului kanak-kanak dalam usaha memahami struktur tatabahasa yang lebih rumit kerana berkemampuan membuat perbandingan maklumat sedia ada dalam pembelajaran bahasa ibunda dengan bahasa sasaran.

Tahap kepercayaan sederhana pula merujuk kepada dua item kebolehan semula jadi iaitu "kebolehan bertutur dalam bahasa asing memudahkan seseorang mempelajari bahasa yang lain" dan "perempuan dapat mempelajari bahasa Arab dengan lebih baik berbanding lelaki". Tidak ramai pelajar yang bersetuju bahawa seseorang yang mampu bertutur dalam bahasa asing iaitu menguasai lebih daripada satu bahasa lebih mudah mempelajari bahasa yang lain. Begitu juga dengan perbandingan jantina antara lelaki dan perempuan, hanya $25.8 \%$ pelajar bersetuju dan sangat setuju bahawa pelajar perempuan mempunyai kelebihan untuk mempelajari bahasa Arab dengan lebih baik berbanding pelajar lelaki. Kepercayaan yang sederhana pada perbezaan jantina ini mungkin menjelaskan bahawa kebolehan semula jadi dalam pembelajaran bahasa tidak semestinya diwakili oleh jantina tertentu bagi peringkat pembelajaran sekolah menengah.

Pernyataan satu item kebolehan semula jadi yang berada pada tahap rendah ialah "orang yang bijak dalam matematik dan sains tidak bijak dalam mempelajari bahasa Arab". Pada sesetengah keadaan, pelajar cemerlang yang bijak sains dan 
matematik dan memasuki aliran sains mungkin dikategorikan sebagai individu yang cenderung kepada pemikiran logik dan fakta, manakala pelajar yang kurang cemerlang dan berada dalam aliran ekonomi mahupun perakaunan didapati lebih cenderung kepada bidang sastera. Keyakinan pelajar yang rendah pada pernyataan ini menunjukkan bahawa pernyataan ini tidak semestinya benar berlaku. Kenyataan ini mungkin disebabkan kebanyakan pelajar cemerlang yang bijak sains dan matematik (aliran sains) atau ekonomi dan perakaunan (aliran sastera) turut didapati cemerlang dalam pembelajaran bahasa mereka. Justeru, kebolehan semula jadi ini tidak diterima sebagai faktor yang dapat membezakan kebolehan seseorang pelajar menguasai bahasa Arab.

\section{Kesimpulan}

Sikap serta pengalaman lalu dalam pembelajaran bahasa merupakan antara faktor yang dapat mempengaruhi tahap kepercayaan pelajar dalam pembelajaran bahasa. Kepercayaan positif yang terbentuk hasil pembelajaran lalu dapat memotivasikan pelajar untuk mempelajari bahasa Arab dengan lebih gigih. Memandangkan kepercayaan merupakan salah satu aspek yang dapat mempengaruhi pencapaian atau kecekapan berbahasa pelajar, maka guru seharusnya mengetahui bentuk kepercayaan pelajar terhadap pembelajaran bahasa ini. Ini kerana guru merupakan individu penting yang dapat menggilap potensi pelajar dalam pembelajaran bahasa. Dengan mengetahui kepercayaan pelajar, guru dapat menerapkan kepercayaan positif serta menyingkirkan kepercayaan negatif dari semasa ke semasa. Dengan perhatian yang diberikan, setiap pelajar dapat dibantu untuk mengatasi masalah dalam pembelajaran bahasa. Selain itu, guru juga dapat membantu pelajar menetapkan matlamat pembelajaran bahasa Arab jangka panjang yang perlu dicapai semasa pengajian peringkat menengah. Melalui matlamat pembelajaran yang jelas, pelajar akan menjadi lebih bertanggungjawab terhadap perkembangan pelajaran bahasa mereka dari semasa ke semasa. Akhirnya, kajian dalam bidang ini diharapkan dapat diteruskan dengan mengaitkan pelbagai pemboleh ubah dengan kepercayaan untuk mengenal pasti faktor-faktor yang dapat mempengaruhi kepercayaan pelajar terhadap pembelajaran bahasa Arab.

\section{Rujukan}

Abdul Pisal, N. (2012). Istratijiat ta'allum maharatul kalam almustaqdamah bimarkazil lughah: Dirasah maidaniah. (Tesis sarjana yang tidak diterbitkan). Universiti Islam Antarabangsa Malaysia.

Abid, R. A. S. (2012). Investigating EFL Iraqi learners' beliefs about learning English as a foreign language. Journal of the College of Arts, (60), 46-81.

Akbari, M., \& Youran, M. (2013). Assessing ESP learners' beliefs about language learning: a survey in an Iranian local context. The International Journal of Language Learning and Applied Linguistics World, 3(2), 73-82.

Aladdin, A. (2012). Analisis penggunaan strategi komunikasi dalam komunikasi lisan bahasa Arab. GEMA Online ${ }^{T M}$ Journal of Language Studies, 12(2), 645-666. 
Bagherzadeh, H. (2012). Language learning beliefs of non-English majors: Examining the role of English language proficiency. Journal of Language Teaching and Research, 3(4), 784-792.

Banya, K., \& Cheng, M. H. (1997). Beliefs about foreign language learning: A study of beliefs of teachers' and students' cross cultural settings. 31st Annual Meeting of the Teachers of English to Speakers of Other Languages (pp. 135). Orlando, Florida, USA.

Brophy, J. (2004). Motivating students to learn. ( ${ }^{\text {nd }}$ ed.). Mahwah, New Jersey: Lawrence Erlbaum Associates, Publishers.

Daud, N., \& Abdul Pisal, N. (2014). Permasalahan pertuturan dalam bahasa Arab sebagai bahasa kedua. GEMA Online Journal of Language Studies, 14(1), 117-133.

Eccles, J. S., \& Wigfield, A. (2002). Motivational beliefs, values, and goals. Annu. Rev. Psychol, 53, 109-132.

Ee, A. M. (2002). Psikologi pendidikan III (semester III). (Ed. ke-3). Shah Alam: Penerbit Fajar Bakti Sdn. Bhd.

Eggen, P., \& Kauchak, D. (2010). Educational psychology windows on classrooms. $\left(9^{\text {th }}\right.$ ed.). New Jersey: Pearson Education.

Fraenkel, J. R., \& Wallen, N. E. (1990). How to design and evaluate research in education. New York: McGraw-Hill.

Horwitz, E. K. (1987). Surveying student beliefs about language learning. In A. L. Wenden \& J. Robin (Eds.), Learner strategies in language learning (pp. 119129). London: Prentice Hall.

Horwitz, E. K. (1988). The beliefs about language learning of beginning university foreign language students. The Modern Language Journal, 72(3), 283-294.

Huang, Z. (2006). Learner beliefs of language learning revisited. Sino-US English Teaching, 3(3), 62-67.

Husin, K. (2010). Psikologi pembelajaran. Kuala Lumpur: Utusan Publications \& Distributors Sdn. Bhd.

Jafari, S. M., \& Shokrpour, N. (2012). The beliefs of Iranian ESP students about language learning. Journal of Educational and Social Research, 2(3), 157-163.

Javadi, J., Jahandar, S., \& Khodabandehlou, M. (2012). A study on the relationship between Iranian EFL learners' beliefs and their writing ability. International Journal of Applied Linguistics \& English Literature, 1(4), 161-172.

$\mathrm{Li}, \mathrm{F}$. (2010). Relationship between EFL learners' belief and learning strategy use by English majors in vocational colleges. Journal of Language Teaching and Research, 1(6), 858-866.

Mohamad, A. B. (2009). Tahap komunikasi dalam bahasa Arab dalam kalangan pelajar sarjana muda bahasa Arab di IPTA Malaysia. Journal of Islamic and Arabic Education, 1(1), 1-14.

Mokhtari, A. (2007). Language learning strategies and beliefs about language learning: a study of university students of Persian in the United States. (Unpublished doctoral dissertation). University of Texas, Austin.

Muijs, D. (2004). Doing quantitative research in education with SPSS. London: SAGE Publications, Ltd. 
Rashid, N. A., Boon, P. Y., \& Syed Ahmad, S. F. (2009). Murid dan alam belajar. Shah Alam: Oxford Fajar Sdn. Bhd.

Oxford, R. L. (1990). Language learning strategies: What every teacher should know. Boston: Heinle \& Heinle.

Rubin, J. (1975). What the "good language learner" can teach us. TESOL Quarterly, 9(1), 41-51.

Schunk, D. H. (2001). Self-regulation through goal setting. ERIC Digest, 1-2.

Sioson, I. C. (2011). Language learning strategies, beliefs, and anxiety in academic speaking task. Philippine ESL Journal, 7, 3-27.

Tercanlioglu, L. (2005). Pre-service EFL teachers' beliefs about foreign language learning and how they relate to gender. Electronic Journal of Research in Educational Psychology, 5-3(1), 145-162.

Wenden, A. (1986). Helping language learners think about learning. ELT Journal, 40(1), 3-12. 